\title{
Migration Patterns of Newfoundland West Coast Herring, Clupea harengus, as shown by Tagging Studies
}

\author{
J. A. Moores and G. H: Winters \\ Department of Fisheries and Oceans, Fisheries Research Branch \\ Northwest Atlantic Fisheries Centre, P. O. Box 5667 \\ St. John's, Newfoundland, Canada A1C 5X1
}

\begin{abstract}
Migration patterns of Atlantic herring in western Newfoundland waters were elucidated from eight tagging experiments in 1975-80 involving both spring and autumn spawners. A total of 43,700 external tags were applied from which 1,062 recaptures were reported to the end of 1981 . The spatial and temporal distribution of the returns indicated that the western Newfoundland herring populations are discrete from stocks in adjacent areas, although extensive mixing occurs during part of the year, particularly outside the spawning season. The Strait of Belle Isle appears to be an important summer feeding area for the western Newfoundland herring populations and, to a lesser degree, for herring from northeastern Newfoundland and the southern Gulf of St. Lawrence. These results were utilized in establishing the boundaries for management of the western Newfoundland stock complex. These boudaries are considered appropriate for the current herring fisheries which exploit both spring and autumn spawners, but smaller management zones would be desirable if the fisheries become concentrated on exploitation of spawning herring.
\end{abstract}

\section{Introduction}

The west coast has been traditionally a major herring fishing area of insular Newfoundland (Fig. 1). Historically, the magnitude of the fishery was determined by the availability of markets. According to Templeman (1966), catches averaged about 15,000 tons annually during the late 1940's. These catches

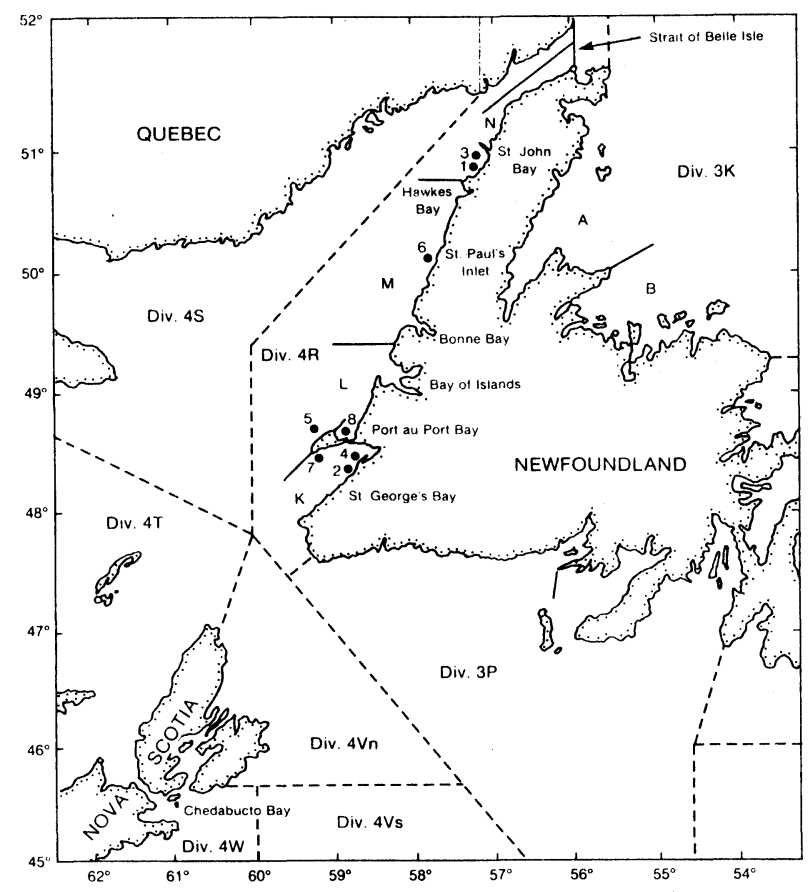

Fig. 1. Map of Newfoundland region showing statistical areas and place names mentioned in the text, and the tagging locations numbered as in Table 1. reflected the favorable market conditions created by the United Nations Relief and Rehabilitation Administration (UNRRA) aid programs for Europe following the Second World War. The cessation of these programs about 1950 led to a decline in herring catches which remained at a low level until the late 1960's. A general expansion of the herring fisheries in eastern Canada occurred in the mid-1960's, due largely to the decline in herring stocks of the Northeast Atlantic and the collapse of the British Columbia herring fishery (Moores, 1980). Major herring fisheries, initially for meal production, developed along southwestern Newfoundland and in the southern Gulf of St. Lawrence (Winters and Hodder, 1975), with some expansion of fishing activity. along western Newfoundland.

The Bay of Islands and Port au Port areas of western Newfoundland (Fig. 1) were the major centers of the herring fishery in the 1940's (Templeman, 1966), but the fishery occurred primarily north of Bay of Islands during the late 1960's and early 1970's, being concentrated initially in Bonne Bay with a gradual shift northward to Hawke's Bay in 1971-72 and to St. John Bay in 1973. This latter fishery was conducted primarily with purse seines during late autumn and early winter and to a limited extent with gillnets throughout the year.

The purse seiners, which operated along western Newfoundland, also participated in the herring fishery along the western half of the south coast, exploiting overwintering concentrations of the southern Gulf of St. Lawrence herring stock (Winters and Hodder, 1975). The decline in abundance of this stock in the early 1970 's led to an expansion of searching activity in 
St. George's Bay in an attempt to offset reduced catches. By 1975, a fishery on prespawning concentrations of herring had developed in St. George's and Port au Port bays. The purse-seine fishery along western Newfoundland since 1975 has consisted of a spring fishery south of Bay of Islands and an autumn fishery north of Bay of Islands. In the late 1970's, there was a major expansion of the gillnet fishery, which resulted in a catch of 19,000 tons in 1980 .

The increased exploitation of herring in eastern Canada during the 1960's generated an expansion of research activity directed toward providing a scientific basis for management of the stocks. Early studies of herring along western Newfoundland characterized the fish as being spring spawners (Tibbo, 1956; Olsen, 1961), with spawning mainly in St. George's Bay, Port au Port Bay, and St. Paul's Inlet. During the 1960's, autumn spawners became increasingly important (Hodder, 1966) and were dominant in the population until the mid-1970's, after which spring spawners again became dominant (Moores, MS 1980).

Tagging experiments, conducted on the west and southwest coasts of Newfoundland in the early 1970's, indicated significant seasonal movement of herring between the southern Gulf of St. Lawrence and southwestern Newfoundland (Winters and Beckett, 1978). Since then, the winter herring fishery along southwestern Newfoundland has ceased, and the spawning and age compositions of herring along the west coast have changed substantially. The purpose of this paper is to examine recent migration patterns of herring from tagging experiments in the late 1970's for comparison with earlier observations.

\section{Materials and Methods}

During 1975-80, 43,700 herring were tagged at various locations along western Newfoundland (Fig. 1). The fish were obtained from purse seines and herring poundnets operated by commercial fishermen. Both gears are non-selective with regard to the size of herring captured and provided fish in good condition for tagging. The headrope along one side of a holding poundnet $(6 \mathrm{~m} \times 6 \mathrm{~m} \times 6 \mathrm{~m})$ was attached to the headrope of the commercial gear, and a supply of herring was transferred to the holding poundnet by depressing the headropes. Batches of 20-30 herring at a time were transferred by dipnet from the holding poundnet to a plastic tub placed in the bottom of a small boat. Seawater in the tub was changed after every second batch of fish were tagged. The tagging team consisted of two persons, one who held the fish as the other inserted the tag into the musculature beneath the dorsal fin. The tagged fish were immediately released over the side of the boat.
Four types of external tags were used in the experiments: anchor (Fly FD-68), short anchor (Floy FD68D), dart (Floy FT-2), and streamer (Floy FTSL-73). Except for some orange streamer and short anchor tags, most of the tags were yellow. A reward of $\$ 3.00$ (Can.) was offered for each tag returned with information on date, place and method of capture. In cases where such data were absent or suspect, contact with the person who returned the tag often resulted in more complete information than was initially provided. In view of the relatively small number of tag returns from these experiments, no distinction among tag types and colors was made for this study of migration patterns.

The number of tagged herring recaptured is dependent not only on the ratio of marked to unmarked fish in the sampled population but also on the rate of exploitation on the various components of the population. In the absence of comparative fishing effort data for the spatial and temporal ranges of the recapture data, the tag returns are expressed in terms of number per 1,000 tons of catch. Monthly herring catches in the various statistical areas were obtained from official records of the Economics and Statistics Branch, Department of Fisheries and Oceans, St. John's, Newfoundland.

During each tagging experiment, random samples of herring were collected and analyzed for age and spawning-type compositions. Ages were determined from otoliths, and the spawning type (spring or autumn) was assigned on the basis of maturity stage relative to the maturation cycle for the two types. Maturity scales were assigned according to the 8-point scale, which was recommended by ICES (1962) and adopted for use in investigations of herring in the Northwest Atlantic (ICNAF, 1964).

\section{Results}

\section{Spatial pattern of tag returns}

The results from the eight tagging experiments reported here (Table 1) encompass both the spring and autumn herring fisheries in the four statistical areas $(K$, $L, M, N)$ which comprise the west coast of Newfoundland (Fig. 1). From a total of 43,700 external tags applied during 1975-80, 1,062 were returned by the end of 1981 , the overall return rate being $2.4 \%$. This rate is lower than those reported by Winters and Beckett (1978) for non-spawning herring marked with internal tags during the early 1970's and much lower than the exploitation rates estimated from virtual population analysis of the west coast herring populations (Moores, MS 1980). Recent analyses of markrecapture data for herring, involving external tags such as those used in this study (B. Nakashima, Northwest 
TABLE 1. Tag returns by area and year from releases of tagged herring at various localities along western Newfoundland during 1975-80. Values in parentheses represent returns per 1,000 tons of herring caught.

\begin{tabular}{|c|c|c|c|c|c|c|c|c|c|c|c|}
\hline \multirow{2}{*}{\multicolumn{2}{|c|}{ Tagging location }} & \multirow{2}{*}{$\begin{array}{l}\text { Time of } \\
\text { tagging }\end{array}$} & \multirow{2}{*}{$\begin{array}{l}\text { Number } \\
\text { tagged }\end{array}$} & \multirow{2}{*}{$\begin{array}{l}\text { Year of } \\
\text { recapt. }\end{array}$} & \multicolumn{6}{|c|}{ Returns by statistical area (see Fig. 1) } & \multirow{2}{*}{$\begin{array}{l}\text { Total } \\
\text { returns }\end{array}$} \\
\hline & & & & & $\mathrm{K}$ & L & M & $\mathrm{N}$ & $A+B$ & Other & \\
\hline \multirow[t]{2}{*}{1.} & Reef Harbour (N) & Jul 1975 & 2,100 & 1975 & - & - & - & $8(7.8)$ & - & - & 8 \\
\hline & & & & 1976 & $1(0.2)$ & - & - & - & 1 & - & 2 \\
\hline \multirow[t]{4}{*}{2.} & St. George's Bay (K) & Apr 1976 & 6,400 & 1976 & $98(14.9)$ & $1(0.5)$ & - & $1(0.8)$ & - & - & 100 \\
\hline & & & & 1977 & $46(8.3)$ & - & - & $1(0.2)$ & - & - & 47 \\
\hline & & & & 1978 & $9(1.3)$ & $1(0.5)$ & - & - & - & - & 10 \\
\hline & & & & 1979 & - & - & $1(0.3)$ & - & - & - & 1 \\
\hline \multirow[t]{6}{*}{3.} & St. John Bay (N) & Dec 1976 & 10,000 & 1976 & - & - & - & $11(8.8)$ & - & - & 11 \\
\hline & & & & 1977 & $114(20.5)$ & $11(5.0)$ & - & $12(2.8)$ & 3 & $2^{\mathrm{a}}$ & 142 \\
\hline & & & & 1978 & $13(1.9)$ & - & $1(2.7)$ & $3(0.5)$ & - & - & 17 \\
\hline & & & & 1979 & $5(0.8)$ & $7(1.4)$ & - & $1(0.3)$ & - & $1^{\mathrm{b}}$ & 14 \\
\hline & & & & 1980 & - & $2(0.3)$ & - & - & 1 & - & 3 \\
\hline & & & & 1981 & $1(0.3)$ & - & - & - & - & - & 1 \\
\hline \multirow[t]{4}{*}{4.} & Sandy Point (K) & Apr 1977 & 7,500 & 1977 & $386(69.3)$ & $11(5.0)$ & $1(6.4)$ & $3(0.7)$ & - & - & 401 \\
\hline & & & & 1978 & $23(3.4)$ & - & - & - & - & - & 23 \\
\hline & & & & 1979 & $5(0.8)$ & $2(0.4)$ & - & - & - & - & 7 \\
\hline & & & & 1980 & - & $1(0.1)$ & - & - & - & - & 1 \\
\hline \multirow[t]{4}{*}{5.} & Port au Port (L) & May 1977 & 2,000 & 1977 & - & $6(2.7)$ & - & $5(1.2)$ & - & - & 11 \\
\hline & & & & 1978 & $6(0.9)$ & $1(0.5)$ & $2(5.5)$ & $2(0.3)$ & - & - & 11 \\
\hline & & & & 1979 & - & - & - & - & - & $1^{\mathrm{b}}$ & 1 \\
\hline & & & & 1980 & - & - & - & $1(0.2)$ & - & - & 1 \\
\hline \multirow[t]{3}{*}{6.} & St. Paul's Inlet (M) & May 1978 & 6,500 & 1978 & - & - & $112(307.9)$ & $8(1.2)$ & - & - & 120 \\
\hline & & & & 1979 & - & $1(0.2)$ & $1(0.3)$ & $1(0.3)$ & - & - & 3 \\
\hline & & & & 1980 & - & $2(0.3)$ & $4(1.4)$ & - & - & - & 6 \\
\hline \multirow[t]{3}{*}{7.} & St. George's Bay (K) & Apr 1979 & 5,200 & 1979 & $5(0.8)$ & $65(12.9)$ & $4(1.0)$ & $1(0.3)$ & - & - & 75 \\
\hline & & & & 1980 & $2(0.4)$ & $2(0.3)$ & $2(0.7)$ & - & - & - & 6 \\
\hline & & & & 1981 & $4(1.1)$ & - & - & - & - & - & 4 \\
\hline \multirow[t]{3}{*}{8.} & Port au Port (L) & Apr 1980 & 4,000 & 1980 & - & $30(4.3)$ & - & $1(0.2)$ & - & - & 31 \\
\hline & & & & 1981 & - & $5(1.0)$ & - & - & - & - & 5 \\
\hline & \multicolumn{2}{|c|}{ Totals } & 43,700 & & 718 & 148 & 128 & 59 & 5 & 4 & 1,062 \\
\hline
\end{tabular}

${ }^{a}$ One return from the northern Gulf (Div. 4S) and one from Chedabucto Bay (Div. 4W).

b This return from the southern Gulf (Div. 4T).

Atlantic Fisheries Centre, St. John's, Newfoundland, pers. comm.), indicated that such tags cause substantial tagging mortality.

Returns from the eight tagging experiments were almost exclusively $(99.2 \%)$ from the west coast of Newfoundland, and $71.3 \%$ of the recoveries occurred within the year of tagging. Only 9 tags were recovered in areas outside the western Newfoundland region, all in years subsequent to the tagging year: 5 from northeastern Newfoundland (Areas A and B), 1 from the northern Gulf of St. Lawrence (Div. 4S), 2 from the southern Gulf of St. Lawrence (Div. 4T), and 1 from Chedabucto Bay, Nova Scotia (Div. 4W).

Biological samples collected during tagging operations (Fig. 2 and 3 ) indicate that the various experiments may be grouped into three categories: (1) homogeneous concentrations, with regard to spawning of herring which were tagged on or near the spawning grounds; (2) prespawning mixtures of spring and autumn spawners which were tagged in areas distant from the spawning sites; and (3) summer-feeding and prewintering concentrations of predominantly springspawning herring.

The first group includes four tagging experiments $(2,4,6$ and 8$)$ involving mainly mature fish in spawning condition. The return from these experiments, adjusted for catch (Table 2), came predominantly from the area of tagging and. showed the least degree of disperson to adjacent areas. This pattern of returns is consistent with the strong homing tendency of Atlantic herring (Wheeler and Winters, 1984).

The second category of tagged herring includes experiments 5 and 7 , from which the returns, adjusted for catch, were fairly dispersed, with the highest return rate in areas immediately adjacent to the areas of release. The dispersion of the tag recaptures is consistent with the mixed spawning-type composition of the tagged fish which primarily were enroute to their spawning grounds along the west coast of Newfoundland. 


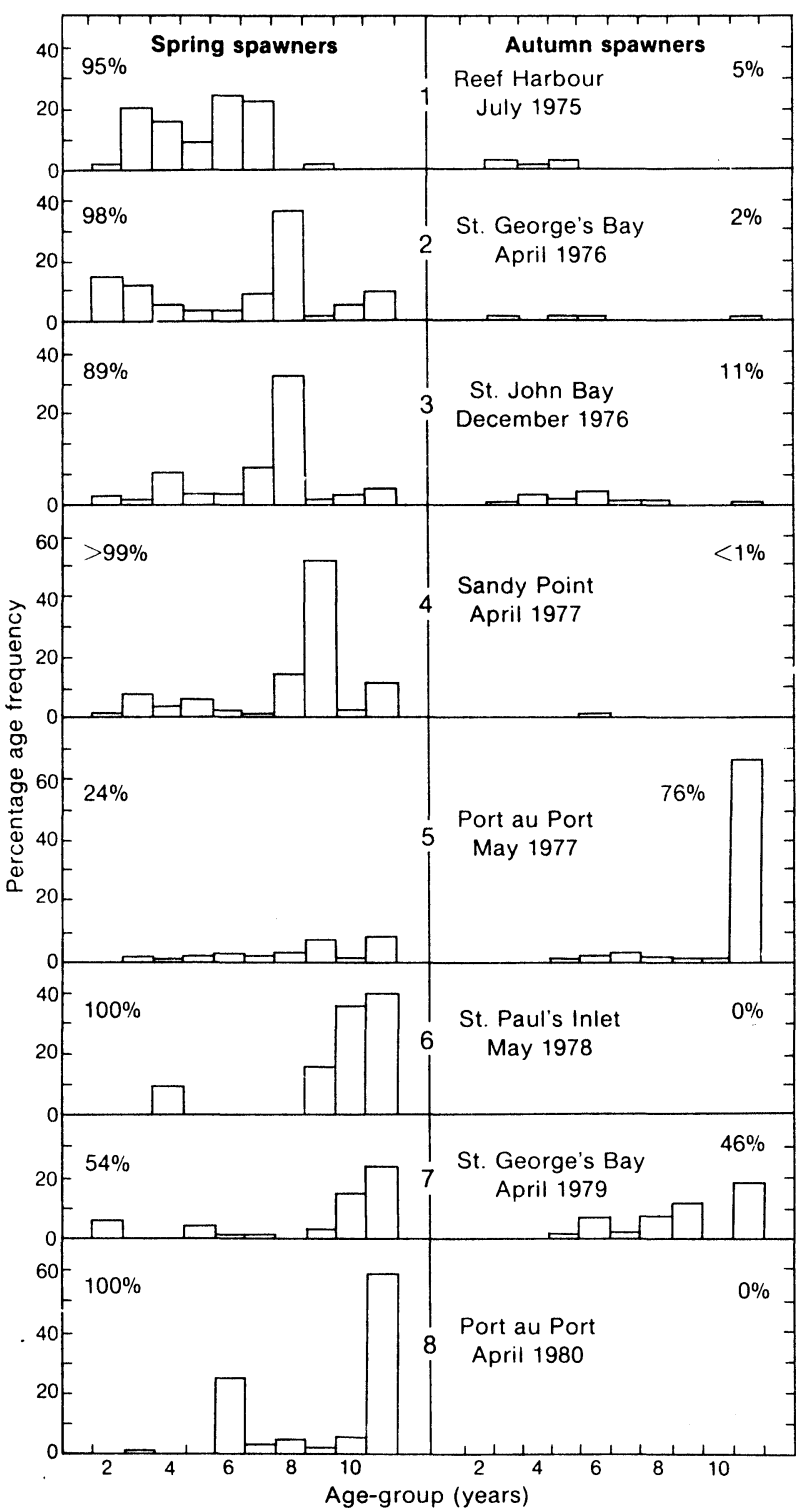

Fig. 2. Age and spawning-type composition of herring sampled during the eight tagging operations along western Newfoundland, $1975-80$.

The third category of tagged herring includes experiments 1 and 3 . Tag returns from these releases, adjusted for catch, indicate a wide range of dispersion with recaptures in the other areas of the Gulf of St. Lawrence (Div. 4S and 4T) and along northeastern Newfoundland (Areas $A$ and $B$ ). These returns indicate that the northern Gulf of St. Lawrence may be an important feeding area for a mixture of herring stocks.

\section{Seasonal pattern of tag returns}

There were no recaptures of tagged herring in the first quarter of the year, due presumably to the low level of catch (Table 2). The majority $(85.5 \%)$ of recaptures occurred in the second quarter, with 5.8 and $10.7 \%$ in

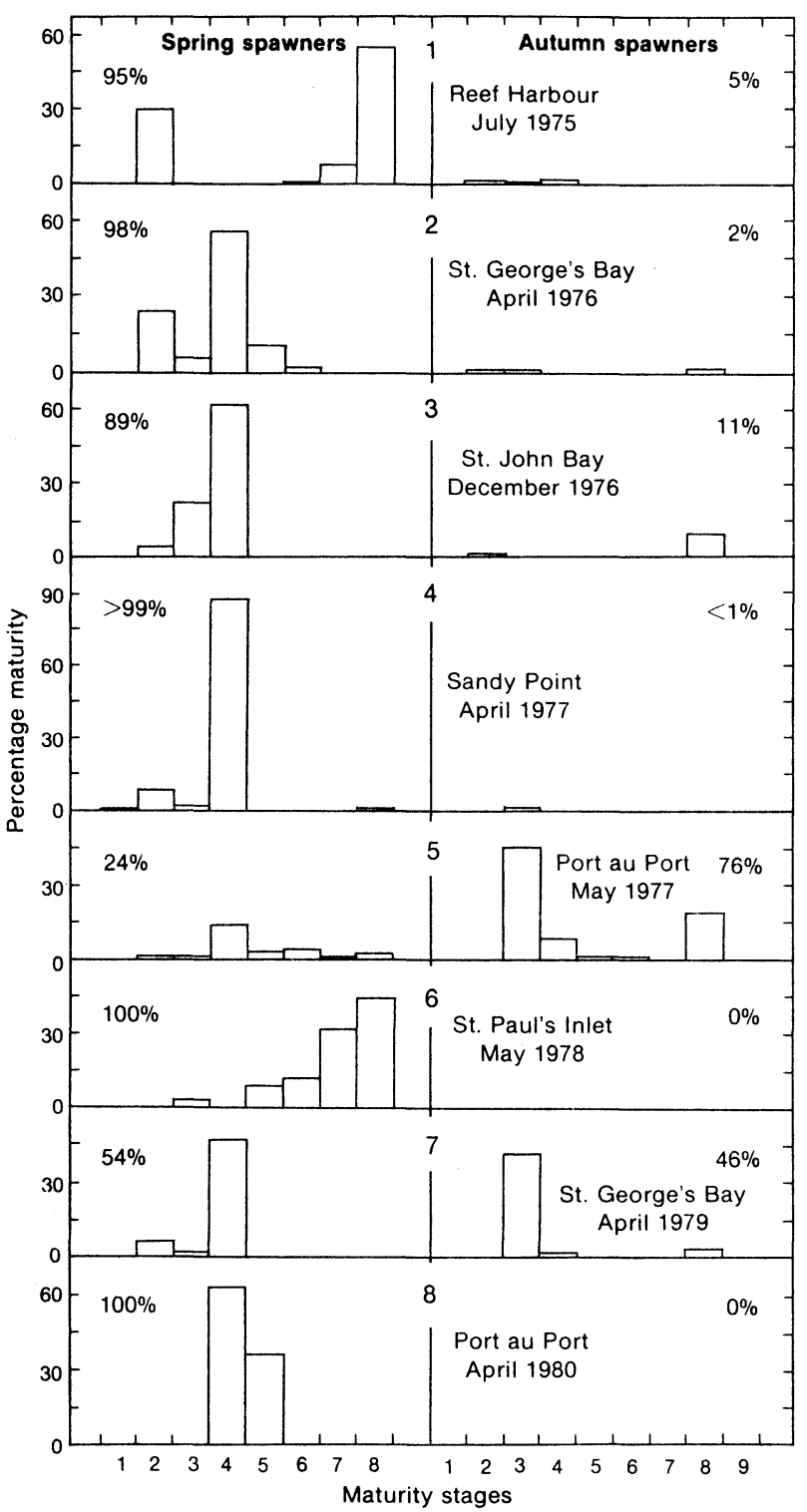

Fig. 3. Maturity-stage composition (by spawning type) of herring sampled during the eight tagging operations along western Newfoundland, 1975-80.

the third and fourth quarters respectively. This temporal pattern of tag returns is mainly a reflection of fishing effort, because the return rates are high for all quarters when tag recoveries are adjusted for catch. The pattern of returns (adjusted for catch) by area and quarter indicates a northward movement during the year, with most returns from the southern areas during the second quarter and predominantly from the northern areas during the fourth quarter.

\section{Discussion and Conclusions}

On the basis of the tagging results, the herring fisheries in the northeastern Gulf of St. Lawrence 
TABLE 2. Summary of tag returns (actual numbers and numbers per 1,000 tons of herring caught) by quarter of year and area of recapture for herring tagged in the four statistical areas of western Newfoundland.

\begin{tabular}{|c|c|c|c|c|c|c|c|c|c|c|c|c|}
\hline \multirow{2}{*}{$\begin{array}{l}\text { Quarter } \\
\text { of year }\end{array}$} & \multirow{2}{*}{$\begin{array}{l}\text { Area of } \\
\text { recapt. }\end{array}$} & \multicolumn{5}{|c|}{ Actual numbers of returns ${ }^{a}$} & \multicolumn{4}{|c|}{ Returns per 1,000 tons caught ${ }^{a}$} & \multirow{2}{*}{$\begin{array}{l}\text { Total } \\
\text { catch }\end{array}$} & \multirow{2}{*}{$\begin{array}{c}\text { Returns } \\
1,000 \mathrm{t} .\end{array}$} \\
\hline & & $\mathrm{K}$ & $\mathrm{L}$ & $\mathrm{M}$ & $\mathrm{N}$ & Total & $\mathrm{K}$ & $L$ & $\mathrm{M}$ & $\mathrm{N}$ & & \\
\hline \multirow[t]{4}{*}{1} & $\mathrm{~K}$ & - & - & - & - & - & - & - & - & - & 46 & - \\
\hline & $L$ & - & - & - & - & - & - & - & - & - & 21 & - \\
\hline & $M$ & - & - & - & - & - & - & - & - & - & 128 & - \\
\hline & $\mathrm{N}$ & - & - & - & - & - & - & - & - & - & 13 & - \\
\hline \multirow[t]{4}{*}{2} & K & 88 & 6 & - & 134 & 228 & 3.3 & 0.3 & - & 4.0 & 33,530 & 6.8 \\
\hline & $L$ & 81 & 6 & 2 & 20 & 109 & 3.7 & 0.3 & 0.2 & 0.9 & 22,011 & 5.0 \\
\hline & $M$ & - & 1 & 4 & - & 5 & - & 0.9 & 3.8 & - & 1,371 & 3.6 \\
\hline & $N$ & - & - & 1 & - & 1 & - & - & 1.4 & - & 696 & 1.4 \\
\hline \multirow[t]{4}{*}{3} & $\mathrm{~K}$ & 1 & - & - & - & 1 & 9.2 & - & - & - & 109 & 9.2 \\
\hline & $\mathrm{L}$ & - & 3 & 1 & - & 4 & - & 13.2 & 4.8 & - & 233 & 17.2 \\
\hline & $M$ & 1 & 1 & 1 & 1 & 4 & 2.4 & 2.4 & 2.5 & 2.5 & 422 & 9.5 \\
\hline & $N$ & - & 1 & 3 & 3 & 7 & - & 0.1 & 0.3 & 0.3 & 10,578 & 0.7 \\
\hline \multirow[t]{5}{*}{4} & $\mathrm{~K}$ & - & - & - & - & - & - & - & - & - & 24 & - \\
\hline & $L$ & 2 & 3 & - & - & 5 & 2.3 & 3.4 & - & - & 875 & 5.7 \\
\hline & $M$ & 7 & - & - & - & 7 & 0.8 & - & - & - & 8,877 & 0.8 \\
\hline & $N$ & 6 & 8 & 5 & 13 & 32 & 0.6 & 8.2 & 0.7 & 1.3 & 10,105 & 3.2 \\
\hline & Total & 186 & 29 & 17 & 171 & 403 & 5.6 & 1.3 & 1.6 & 7.8 & 89,039 & 4.5 \\
\hline
\end{tabular}

\footnotetext{
a Exclude recaptures in the tagging area during the year of tagging.
}

exploit a mixture of stocks, with the degree of heterogeneity varying according to the area and season of the fishery. The populations appear to be fairly discrete during the spawning season, whereas components of several stocks are exploited during the feeding season in the extreme northeastern area of the Gulf, including those from northeastern Newfoundland and from the southern part of the Gulf. It is, however, significant that the return rates of tags (i.e. numbers per 1,000 tons of catch) for the northern areas of western Newfoundland ( $M$ and $N$ ) in the third and fourth quarters of the year are not substantially lower than those for the southern areas ( $K$ and $L$ ) in the second quarter. This implies that the feeding concentrations are predominantly herring which spawn in the northern areas, with insignificant contributions from other areas (e.g. Div. 3K and 4T).

The pattern of seasonal returns indicates that, subsequent to spawning, there is a general northward migration to the Strait of Belle Isle where summer feeding occurs. This northward feeding migration is similar to that observed in herring stocks of eastern Newfoundland (Tibbo, 1956; J. P. Wheeler, Northwest Atlantic Fisheries Centre, St. John's, Newfoundland, pers. comm.). The exact area of overwintering of these populations have yet to be determined, but the timing of the purse-seine fishery during the spring along the southern part of the coast and the apparent overlap of western Newfoundland and southwestern Newfoundland stocks (Winters and Beckett, 1978) indicate that overwintering occurs along the southern part of the west and possibly the western part of the south coast of Newfoundland. This implies a southward migration along the west coast in late autumn or winter from the summer-autumn feeding area in the Strait of Belle Isle. Nevertheless, emigration of herring from the northern Gulf of St. Lawrence during winter is not complete, because incidental catches of herring during groundfish surveys in the northern Gulf (G. R. Lilly, Northwest Atlantic Fisheries Centre, St. John's, Newfoundland, pers. comm.) show a widely dispersed distribution of herring during the winter.

Analysis of the extensive tagging experiments presented in this paper supports the findings from previous studies on the identity of the herring stock in the northeastern Gulf of St. Lawrence. Parsons and Hodder (1971), from the incidence of larval nematodes in various Northwest Atlantic stocks, concluded that herring along the northwest coast of Newfoundland were distinct from those constituting the southwestern Newfoundland-southern Gulf of St. Lawrence stock complex. They noted that the incidence of nematodes in herring from Bonne Bay and Bay of Islands was lower than in fish from the Strait of Belle Isle and concluded that herring from the southern part of the west coast may contribute to the winter fishery along southern Newfoundland. On the basis of meristic characteristics, Parsons (1973) also concluded that herring in the northern Gulf were distinct from those in southwestern Newfoundland waters, but that the autumn-spawning components of catches in the autumn fishery at Hawkes Bay may represent herring which are enroute by a circuitous route from the southern Gulf of St. Lawrence to overwinter in southwestern Newfoundland waters. This relationship between prewintering concentrations of herring in the Strait of Belle Isle and the southern Gulf-southwestern New- 
foundland stock complex was also evident in the pattern of tag recaptures from a small tagging experiment at Hawkes Bay in December 1970 (Moores, MS 1980). These studies, taken together, confirm that western Newfoundland herring are essentially discrete from those in adjacent areas but that the Strait of Belle Isle may be an important feeding area for widely dispersed populations of herring in summer.

The present management regime for herring in western Newfoundland waters include the area within the boundaries of NAFO Div. 4R. As long as the herring fisheries within this management zone continue to exploit both spawning and prewintering concentrations of herring, the zone is an appropriate reference for stock assessment purposes. However, in view of the homing tendency of Atlantic herring (Wheeler and Winters, 1984), if the fishing pattern changes to exclusive exploitation of spawning fish, a management regime based on individual spawning populations would be desirable.

\section{Acknowledgements}

We thank Dr J. Green, Memorial University of Newfoundland, St. John's, for his supervision of the thesis from which part of this paper is derived. We also thank the technical staff of the Pelagic Fish Section, Fisheries Research Branch, Northwest Atlantic Fisheries Centre, St. John's, Newfoundland, for assistance in data collection and collation, and Dr J. Carscadden who provided many helpful comments on the initial draft of the manuscript.

\section{References}

HODDER, V. M. 1966. Recent herring investigations in Newtoundland waters. Canadian Fish. Rep., 8: 39-54.

MOORES, J. A. 1980. The herring resource of eastern Canada. In Proceedings of the Alaska herring symposium, B. R. Melteff and V. G. Wespested (ed.), Alaska Sea Grant Rep. No. 80-4, p. 179-206. MS 1980. Population dynamics and biological characteristics of the Newfoundland west coast herring stock. M.Sc. Thesis, Memorial University of Newfoundland, St. John's, Nfld., Canada, $82 \mathrm{p}$.

OLSEN, S. 1961. Contribution to the biology of herring (Clupea harengus L.) in Newfoundland waters. J. Fish. Res. Bd. Canada, 18: 31-46.

PARSONS, L. S. 1973. Meristic characters of Atlantic herring, Clupea harengus harengus L., stocks in Newfoundland and adjacent waters. ICNAF Res. Bull.: 10: 37-52.

PARSONS, L. S., and V. M. HODDER. 1971. Variation in the incidence of larval nematodes in herring from Canadian Atlantic waters. ICNAF Res. Bull., 8: 5-14.

TEMPLEMAN, W. 1966. Marine resources of Newfoundland. Bull. Fish. Res. Bd. Canada, 154, $170 \mathrm{p}$.

TIBBO, S. N. 1956. Populations of herring (Clupea harengus L.) in Newfoundland waters. J. Fish. Res. Bd. Canada, 13: 449-466.

WHEELER, J. P., and G. H. WINTERS. 1984. Homing of Atlantic herring in Newfoundland waters, as indicated by tagging data. Can. J. Fish. Aquat. Sci., 41: (in press).

WINTERS, G. H., and J. S. BECKETT. 1978. Migrations, biomass and stock interrelationships of southwest Newfoundland-southern Gulf herring from mark-recapture experiments. ICNAF Res. Bull., 13: $67-79$

WINTERS, G. M., and V. M. HODDER. 1975. Analysis of the southern Gulf of St. Lawrence herring stock complex and implications concerning its future management. ICNAF Res. Bull., 11: 43-59. 